\title{
Research Paper: A Novel Nanoparticle-Based Method to Isolate DNA From Dried Saliva and Semen Samples
}

\author{
Mohammed Azim Bagban ${ }^{*}$ (D), Reshma Mansuri' ${ }^{1}$, Nayan Jain ${ }^{1}$ (i) \\ 1. Department of Life Sciences, School of Sciences, Gujarat University, Ahmedabad, India.
}

\begin{tabular}{|c|c|}
\hline $\begin{array}{l}\text { Use your device to san } \\
\text { and read the article online }\end{array}$ & \\
\hline  & Chat on Bagban MA, Mansur1 R, Jain N. A Novel Nanoparticle-Based Method to Isolate DNA From Dried Saliva and Semen \\
\hline (athe & dol https://doi.org/10.32598/jamsat.4.1.13 \\
\hline
\end{tabular}

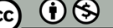

Article info:

Received: 01 Nov 2017

Accepted: 10 Feb 2018

Available Online: 01 Mar 2018

\section{Keywords:}

Nanoparticles, DNA, Saliva, Semen

\section{A B STRACT}

Objectives: Saliva and semen stains may be found at crime scene (suicide, homicide, kidnapping, rape, sexual assault, poisoning, etc.). Through, which DNA can be isolated and individual can be identified. DNA can be of great importance in forensic science investigation to identify individuals. Currently, there are enormous methods to isolate DNA from biological fluids. The current study employed nanoparticle-biomolecule conjugate method to isolate DNA.

Materials \& Methods: A nanoparticle-biomolecule conjugate is a magnetic nanoparticle with biomolecules attached to its surface. Saliva and semen were collected using cotton swabs from different surfaces (tile, steel, aluminum, glass, iron, wood, etc.) on which saliva and semen were poured and allowed to dry earlier as to create simulated crime scene. Magnetic nanoparticles $\left(\mathrm{Fe}_{3} \mathrm{O}_{4}\right)$ act as solid phase support to isolate DNA from saliva and semen stains. In the current study, cells and spermatozoa were extracted from saliva and semen swabs, respectively. Cell lysis was performed to extract epithelial cells from saliva and spermatozoa from semen and magnetic nanoparticles and biomolecule conjugate were added to the lysed cells to bind to DNA.

Results: Application of external magnetic field helped to settle down nanoparticle-biomolecule conjugate and thus separate DNA from other cell components. Spectrophotometer Nanodrop technology was employed to perform the readings, which confirmed the presence of DNA at 260/280 ratio and quality of DNA was compared with the DNA isolated using the two different methods.

Conclusion: The current study aimed at developing all new methods to isolate DNA from dried saliva and semen samples using magnetic nanoparticles by reviewing the methods developed earlier to isolate DNA from blood and tissue using magnetic nanoparticles. With modifications in the method and chemical preparation, a new method was successfully developed. DNA was isolated successfully; and confirmation was made by analyzing DNA through Nanodrop spectrophotometer.

* Corresponding Author:

MohammedAzim Bagban, PhD.

Address: Department of Life Sciences, School of Sciences, Gujarat University, Ahmedabad, India.

Tel: +91 (901) 6512513

E-mail:azim_adi@yahoo.com 


\section{Highlights}

- A newly method is developed to isolate DNA based on nanoparticles from dried saliva and semen samples.

- This method is cost effective and provide a good quality and quantity of DNA.

- Novel nanoparticle-based method was compared with two other methods.

\section{Plain Language Summary}

Saliva and semen found at crime scenes can be considered significant and treated as such. Traditionally saliva at crime scenes has been documented and collected for identification of the suspect or victim through blood grouping and DNA analysis at a crime laboratory. Semen can also be useful for identification of an individual by DNA analysis. Saliva and semen samples, which may found in any crime scene, are in dried condition. Thus, for isolating the DNA from such dried samples, costly kits and skilled handling are required. In the present study, we have developed a nanoparticlesbased method which is not only cost effective but also as effective as kit-based methods. The qualitative and quantitative analysis of isolated DNA from dried saliva and semen samples was done and comparison was also made with two different methods.

\section{Introduction}

NA Isolated from saliva turned into an attractive alternative fluid to the application of blood-derived DNA in molecular field, and currently it is widely used in numerous applications; concern in quick and less destructive analytical tests exponentially grew up in the previous era, which led to widespread research on saliva as a biological material for clinical diagnostic analysis [1]. The salivary fluid has certain benefits compared to urine and blood, two of the utmost used diagnostic fluids in laboratories. Despite the ease in the collection of the saliva sample and noninvasive demanding and comparatively modest instructions for collection, it retains lower protein content, fewer complication and variable composition than serum [2].

The DNA analysis procedure conducted in criminological laboratory is occasionally time consuming, ensuing in the statement that the outcome is not significant and capable to efficiently contribute to the preliminary stage of the criminal case investigation by the police services [3]. Reference samples should be collected along with the crime scene samples in an appropriate manner, which is fast and trouble-free and does not affect the suspect or victim. Usually, swabs are prepared for this determination [4]. Biological evidence is considered as the utmost significant kind of evidence (particularly semen); subsequently, it is quite valuable to prove the occurrence of physical/sexual intercourse and recognize a culprit through DNA identification in rape cases [5-9].
Semen (spermatozoa in the seminal liquid): it is hardly present in oral cavity up to six hours, in anorectal cavity up to 24 hours, and in vaginal cavity up to 72 hours after sexual intercourse [10]. Due to the low possibility of collecting semen sample from victim's body just after a few hours, semen samples collected from the various surfaces and clothing and fabric materials of suspect or victim supported the identification.

The nonappearance of spermatozoa may happen if the suspect is vasectomized, azoospermic, or semen stains dry [9]. Since it is valuable to prove the incidence of sexual intercourse and identify the accused, currently, biological evidence for DNA analysis is considered the most significant evidence for legitimate proof in courts of law [11]. DNA extraction procedures are progressively more in effect since it is possible to get purified DNA from biological evidence. These kinds of DNA extraction procedures develop with respect to the time and some advanced studies in progress.

At present, most of the frequently used procedures of DNA isolation are based on organic extraction in which SDS (Sodium Dodecyl Sulfate) and proteinase-K are used to breakdown the cell membrane and protein digestion. During this procedure, accumulation of proteinase$\mathrm{K}$ quickly deactivates nucleases such as DNases enzyme and RNases enzyme, which might damage DNA during the extraction procedure. Subsequently, DNA is purified by phenol-chloroform mixture; centrifugation is done, and then DNA is precipitated out using alcohol (especially ethanol) and formerly it was re-suspended in buffer containing low salt [12]. 
Magnetic nanoparticles can be influenced by magnetic fields. Such particles usually comprise two constituents, a magnetic material, which comprises iron, cobalt, and nickel and a chemical constituent that has functionality. The purification of the plasmid or genomic DNA using magnetic materials such as matrix or bead is already tried in various biological samples [13]. The naked or uncoated magnetic nanoparticles $\left(\mathrm{Fe}_{3} \mathrm{O}_{4}\right)$ have a specific property to bind reversibly to the DNA under certain circumstances. There are numerous characteristic advantages in which elements are getting adsorbed to the magnetic sustenance.

The particle size is smaller $(100 \mathrm{~nm})$ due to lack of polymer coating, which offers a better surface area to bind to biomolecules. This furthermore permits the particles to have the greatest susceptibility to the magnetic field applied from outside. Additionally, magnetic nanoparticles act as steady colloidal suspension, which do not aggregate or permit even for distribution in a reaction blend. Thus, Saiyed Z M et al., recently stated that naked magnetic nanoparticles can be used as support material to extract or isolate genomic DNA from the cells of mammals [14]. The current study aimed at creating a novel approach to extract genomic DNA using magnetic nanoparticles from dried saliva and semen samples.

\section{Materials and Methods}

\section{Sample collection and preparation}

Saliva and semen samples were the major requirements for the study. Saliva samples were collected from volunteers of Department of Life Sciences, Gujarat University, Ahmedabad, India with care and under the guidance of expert with consent. Semen samples were collected from the Sunflower Laboratory with official consent. In almost all crime scenes when saliva and semen are found as evidence they are in dried form. Therefore, in the current study, the crime scene was simulated in the laboratory.
For the forensic analysis, the collected saliva and semen were left to dry on different surfaces. DNA isolation was performed by preparing the cotton swabs similar to the forensic laboratories. Saliva control and saliva swabs from all surfaces were made from the first day at the interval of five days up to 60 days. Each swab was used for DNA isolation using different methods mentioned below: 1 . Conventional method, which is widely used [15], was slightly modified 2. By GeneiPure ${ }^{\mathrm{TM}}$ Mammalian Genomic DNA Purification Kit; and 3. Magnetic nanoparticles-based method.

\section{Preparation of magnetic nanoparticles}

For this purpose, $1 \mathrm{M} \mathrm{FeSO}_{4} .7 \mathrm{H}_{2} \mathrm{O}(2.78 \mathrm{~g}$ in $10 \mathrm{~mL}$ distilled water) (Merck) was mixed with $2 \mathrm{M} \mathrm{FeCl}_{3}$ (3.24 g in $10 \mathrm{~mL}$ distilled water) (FINAR); $8 \mathrm{M} \mathrm{NH}_{4} \mathrm{OH}$ was added with constant stirring at $24^{\circ} \mathrm{C}$. Precipitations were observed. Impurities such as sulfate ions and chloride ions were eliminated by washing with warm distilled water. Precipitate particles were left to dry at $60^{\circ} \mathrm{C}$ in hot air oven for about 24 hours. Yield precipitates possess magnetic properties. These magnetic particles were stored in Tris EDTA (ethylenediaminetetraacetic acid) buffer $(\mathrm{pH}=8-8.5)$. Nanoparticle characterization was addressed using Malvern Analytical Nano sight NS300 instrument, which allows automated examination of the concentration and size dispersal of all types of nanoparticles ranging 10 to $2000 \mathrm{~nm}$ in diameter.

\section{DNA isolation using magnetic nanoparticles}

Saliva and semen swabs collected from different surfaces were left to dry. Each swab was kept in a microfuge tube. A $200-\mu \mathrm{L}$ of Tris EDTA buffer was added to saliva swabs and $200 \mu \mathrm{L}$ of acidulated water was also added to semen swabs for extraction of epithelial cells and spermatozoa, respectively. Mixed well for 30 minutes and swabs were removed and centrifuged at $3000 \mathrm{rpm}$ for five minutes. Supernatant was removed carefully so that pellet of cells remained undisturbed. To this pallet, $200 \mu \mathrm{L}$ of cell lysing buffer-I (hav-

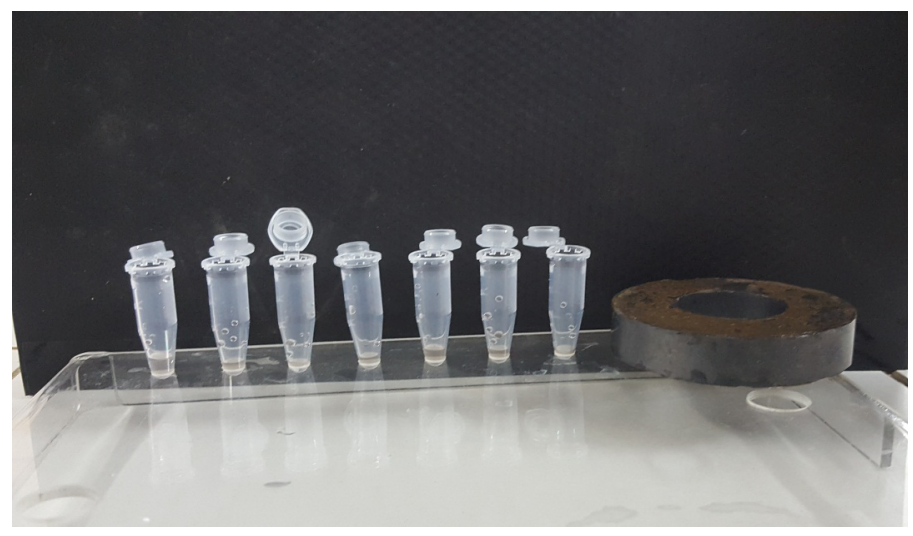

Figure 1. Application of external magnetic field to magnetic-biomolecule conjugate 

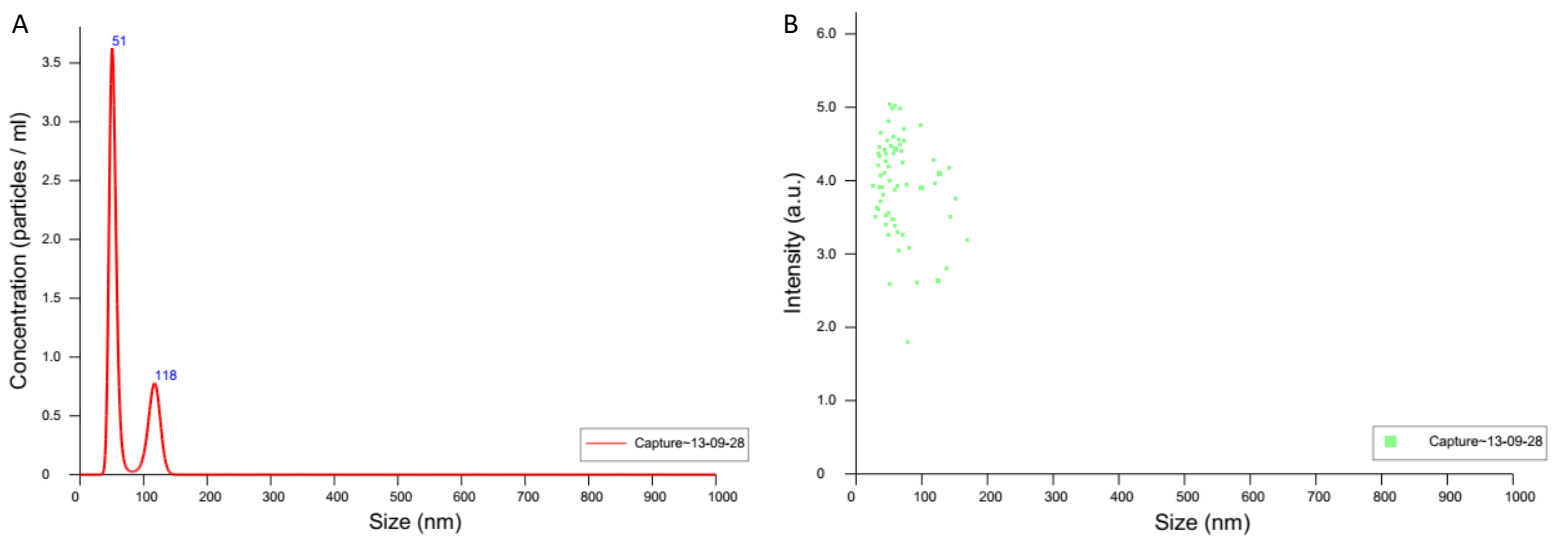

JAMSAT

Figure 2. FTLA concentration/size and intensity/size graph for experiment

(A) Validation of a particle tracking analysis method to determine the size of nanoparticles; (B) Second graph is indicating that the high amount of intensity of magnetic nanoparticles ranged 0 to $100 \mathrm{~nm}$ size and can be observed as green scattered dots

ing $10 \mathrm{mM}$ Tris buffer, $10 \mathrm{mM} \mathrm{KCl}, 10 \mathrm{mM} \mathrm{MgCl}, 0.5 \mathrm{M}$ $\mathrm{NaCl}, 2 \mathrm{mM}$ EDTA, 1\% SDS dissolved in $50 \mathrm{~mL}$ distilled water) for saliva and cell lysing buffer-II for semen (having $10 \mathrm{mM}$ Tris $\mathrm{HCl}, 75 \mathrm{mM} \mathrm{NaCl}, 25 \mathrm{mM}$ EDTA, 1\% SDS and $21 \mu \mathrm{l}$ DTT dithiothreitol) was added.

Solutions were incubated for 20 minutes at room temperature and then, $75-80 \mu \mathrm{L}$ of magnet nanoparticle solution was added. Then $150 \mu \mathrm{L}$ of binding buffer $(1 \mathrm{M} \mathrm{NaCl}+10 \%$ ethylene diol) was added. The mixture was incubated for 30 minutes at $4{ }^{\circ} \mathrm{C}$. DNA bounded to magnetic nanoparticles to form magnetic-biomolecule conjugate [16]. With the help of external magnetic field this magnetic-biomolecule conjugate was separated from all other cell components in the solution as shown in Figure 1. Supernatant was discarded, $70 \%$ ethanol was added to wash magnetic-biomolecule conjugate and the solution was left to dry; $200 \mu \mathrm{L}$ of Tris EDTA buffer was added and incubated for 20 minutes at $65^{\circ} \mathrm{C}$ on shaking in between (DNA was separated from magnetic nanoparticles in the solution). With the help of external magnetic field, these magnetic nanoparticles were allowed to settle down leaving DNA in the solution. Tris EDTA solution residing dissolved DNA was collected in another microfuge tube.

\section{DNA analysis}

DNA extracted from the saliva and semen control and saliva and semen swabs were analyzed using agarose gel electrophoresis and Nanodrop spectrophotometer (Epoch Biotech). Each DNA sample to be analyzed was dissolved in $500 \mu \mathrm{L}$ of Tris EDTA buffer and absorbance ratio of $260 / 280$ and the quality was observed by Nanodrop.

\section{Results}

\section{Nanoparticle validation on nano-sight}

According to Figure 2 the size of magnetic nanoparticles ranged 10 to $118 \mathrm{~nm}$ in which the high peak was obtained

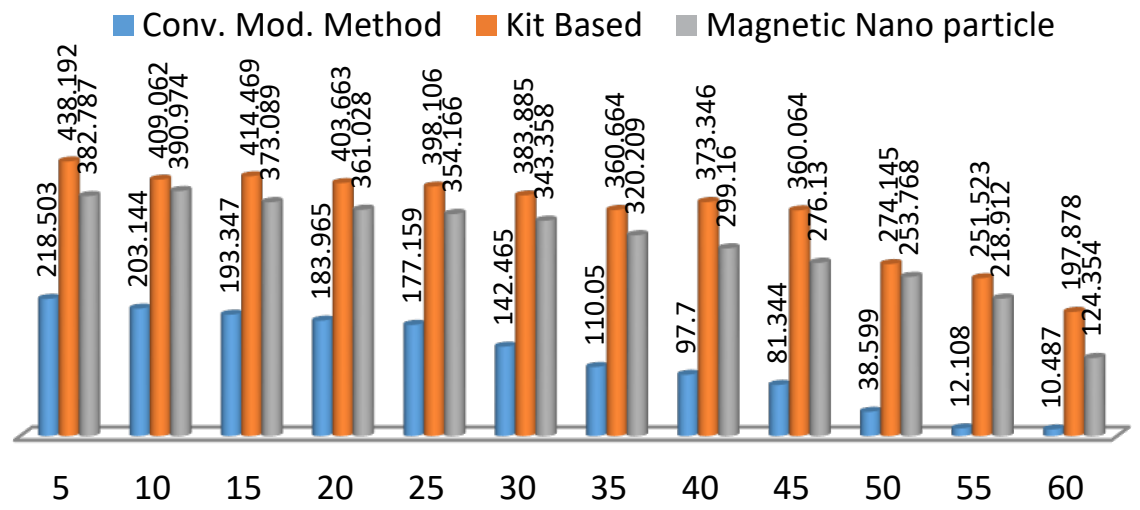

Figure 3. Comparison graph showing quantitative analysis of DNA extracted from saliva sample 


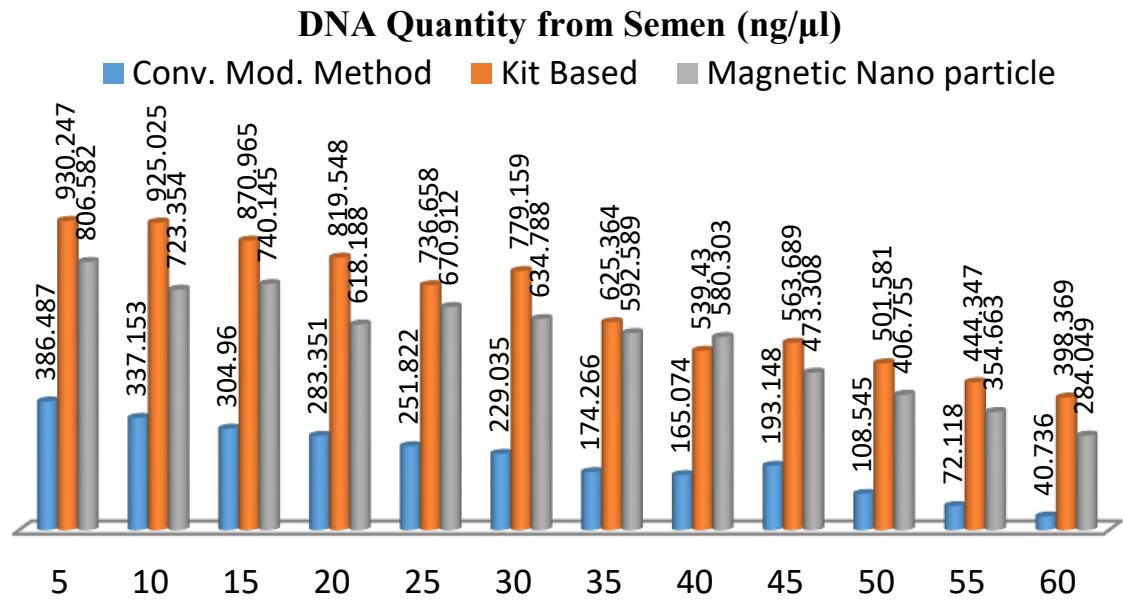

Figure 4. Comparison graph showing quantitative analysis of DNA extracted from semen sample

Table 1. Qualitative data of DNAs extracted from Saliva and semen samples based on time period

\begin{tabular}{cccccccc}
\hline Day & Ratio & \multicolumn{3}{c}{ Saliva Sample } & \multicolumn{3}{c}{ Semen Sample } \\
\cline { 3 - 8 } & & $\begin{array}{c}\text { Conv. Mod. } \\
\text { Method }\end{array}$ & Kit-Based & $\begin{array}{c}\text { Magnetic } \\
\text { Nanoparticle }\end{array}$ & $\begin{array}{c}\text { Conv. Mod. } \\
\text { Method }\end{array}$ & Kit-Based & $\begin{array}{c}\text { Magnetic } \\
\text { Nanoparticle }\end{array}$ \\
\hline 5 & $260 / 280$ & 1.583 & 1.809 & 1.824 & 2.000 & 1.705 & 1.870 \\
\hline 10 & $260 / 280$ & 1.512 & 1.900 & 1.999 & 1.945 & 1.780 & 1.767 \\
\hline 15 & $260 / 280$ & 1.535 & 1.807 & 1.876 & 1.678 & 1.897 & 1.874 \\
\hline 20 & $260 / 280$ & 0.980 & 1.976 & 1.881 & 1.643 & 1.864 & 1.800 \\
\hline 25 & $260 / 280$ & 1.461 & 1.707 & 1.799 & 1.564 & 1.859 & 1.799 \\
\hline 30 & $260 / 280$ & 1.339 & 1.876 & 1.870 & 0.793 & 1.780 & 1.791 \\
\hline 35 & $260 / 280$ & 1.263 & 1.873 & 1.689 & 0.932 & 1.901 & 1.679 \\
\hline 40 & $260 / 280$ & 1.567 & 1.899 & 1.749 & 0.547 & 1.711 & 1.697 \\
\hline 45 & $260 / 280$ & 0.710 & 1.794 & 1.946 & 1.364 & 1.719 & 1.638 \\
\hline 50 & $260 / 280$ & 1.381 & 1.799 & 1.899 & 1.304 & 1.607 & 1.867 \\
\hline 55 & $260 / 280$ & 0.631 & 1.677 & 1.976 & 0.913 & 1.673 & 2.009 \\
\hline 60 & $260 / 280$ & 0.854 & 1.601 & 1.902 & 0.994 & 1.669 & 1.933 \\
\hline
\end{tabular}

JAMSAT

at $51 \mathrm{~nm}$ size. For successful isolation of DNA from the sample, the size of magnetic nanoparticle should range 10 to $100 \mathrm{~nm}$. As the maximum concentration of nanoparticles size was $51 \mathrm{~nm}$, it can be useful to isolate DNA.

DNA analysis

For qualitative analysis of isolated DNA, the absorbance was measured at $260 / 280 \mathrm{~nm}$ ratio to evaluate the purity of DNA and RNA using Nanodrop Spectrophotometer. A ratio of $\sim 1.7$ is generally accepted as "pure" for DNA. If the range is lower than 1.7 , it shows the impurity of protein and if it is above 2.0 then it shows impurity of RNA.

\section{Qualitative analysis of DNA}

According to Table 1, for the saliva samples, 260/280 ratio ranged 0.631 to 1.583 by mod. ${ }^{1}$ Conv. ${ }^{2}$ method indicated the high amount of protein contamination up to 60 days while by kit-based method the ratio ranged 1.601 to 1.976 show-

1. Modified

2. Conventional 
ing decent quality of DNA; and by magnetic nanoparticlebased method, the ratio ranged 1.749 to 1.999 showing good quality of DNA up to 60 days. For semen samples, 260/280 ratio ranged 0.793 to 2.000 for mod. Conv. method showed high contamination of protein as well as RNA, while by kit-based method ratio ranged 1.607 to 1.897 indicating good quality of DNA; and by magnetic-nanoparticle-based method, the ratio ranged 1.638 to 2.009 indicating slight contamination of RNA, which may be due to the interfering microorganisms in the beginning of DNA analysis.

\section{Quantitative analysis of DNA}

Quantity of the DNA is much more beneficial than that of the DNA in forensic examination. Figure 3 indicates the graphical representation of comparison of all the three methods for quantitative analysis of DNA extracted from saliva samples. Quantity of DNA obtained by mod. conv. method was $218.503 \mathrm{ng} / \mu \mathrm{L}$ on the day 5 , which showed consistent descending manner and on the day 60 only $10.487 \mathrm{ng} / \mu \mathrm{L}$. While in the kit-based and nanoparticlebased methods 438.192 and $382.787 \mathrm{ng} / \mu \mathrm{L}$ were amounts of DNA respectively, obtained on the day 5, and up to the day 60 quantity downgraded up to $197.878 \mathrm{ng} / \mu \mathrm{L}$ and $124.354 \mathrm{ng} / \mu \mathrm{L}$ by kit-based and nanoparticle-based methods, respectively. The amount of DNA obtained by magnetic-nanoparticle-based method on the day 60 was closely related to the amount obtained by kit-based method and the amount was also sufficient for further DNA analyses such as Polymerase Chain Reaction (PCR) and Restriction Fragment Length Polymorphism (RFLP).

Figure 4 indicates the graphical representation of comparison of all the three methods for quantitative analysis of DNA extracted from semen sample. Quantity of DNA obtained by mod. conv. method was $386.487 \mathrm{ng} / \mu \mathrm{L}$ on the day 5 , which showed consistent descending manner and on the day 60 only $40.736 \mathrm{ng} / \mu \mathrm{L}$ obtained, while in the kit-based and nanoparticle-based methods the amounts of DNA were 930.247 and $806.582 \mathrm{ng} / \mu \mathrm{L}$, respectively obtained on the day 5, and up to the day 60 quantity downgraded up to 398.369 and $284.049 \mathrm{ng} / \mu \mathrm{L}$ by the kit-based and nanoparticle-based methods, respectively. The amount of DNA obtained by magnetic-nanoparticle-based method on the day 60 was closely related to that of obtained by kit-based method and the amount was sufficient for further DNA analyses such as PCR and RFLP.

\section{Discussion}

Magnetic separation techniques based on magnetic particles covered with diverse polymers such as silica or agarose are used progressively for molecular-based bio- logical applications [17]. Hawkins TL et al., explained the mechanism of carboxyl coated magnetic particles such as BioMag coated with carboxyl used to adsorb the nucleic acids (DNA) in pure form in high-salt environments. They also showed that magnetic $\left(\mathrm{Fe}_{3} \mathrm{O}_{4}\right)$ particles produced by the co-precipitation technique precisely adsorbed the amphoteric hydroxyl $(-\mathrm{OH})$ group that leftovers on the particles between $\mathrm{pH}$ range of 6.0 to 10.0 [16]. The naked or uncoated magnetic nanoparticles $\left(\mathrm{Fe}_{3} \mathrm{O}_{4}\right)$ allow us to utilize their characteristics to bind to DNA reversibly under specific circumstances. There are numerous intrinsic benefits of the application of such naked nanoparticles, where magnetic support allows direct adsorption of biomolecules. The smaller particle sizes $(\leq 100 \mathrm{~nm})$ provide a higher surface area for the attachment of the biomolecules due to the absence of polymer coating; this furthermore permits the particles to have the greatest magnetic susceptibility to the applied magnetic field [16].

\section{Conclusion}

The current study aimed at developing all new methods to isolate DNA from dried saliva and semen samples using magnetic nanoparticles by reviewing the methods developed earlier to isolate DNA from blood and tissue using magnetic nanoparticles. With modifications in the method and chemical preparation, a new method was successfully developed. DNA was isolated successfully; and confirmation was made by analyzing DNA through Nanodrop spectrophotometer. A kit-based method is expensive whereas mod. conv. method shows poor results as compared with the other two methods. Thus, the developed magnetic-nanoparticle-based method is reliable and cost effective as well as less time consuming compared with the other methods.

\section{Ethical Considerations}

\section{Compliance with ethical guidelines}

This study have been approved by the Research Ethics Committee of Gujarat University. Informed consent was obtained from all individual participants included in the study.

\section{Funding}

The current study was funded by UGC MANF Scheme (MANF-2013-14-MUS-GUJ-23554).

\section{Authors contributions}

Conceptualization: All authors; Methodology: MohammedAzim Bagban \& Mansuri Reshma; Investigation: MohammedAzim Bagban \& Reshma MAnsuri; Writ- 
ing - original draft: MohammedAzim Bagban; Writing -review \& editing: MohammedAzim Bagban \& Nayan Jain; Funding acquisition: MohammedAzim Bagban; Resources: All authors; Supervision: Nayan Jain.

\section{Conflict of interest}

The authors declared no conflict of interest.

\section{Referencees}

[1] Sun F, Reichenberger EJ. Saliva as a source of genomic DNA for genetic studies: Review of current methods and applications. Journal of Oral Health and Dental Management. 2014; 13(2):21722. [PMID]

[2] Nunes LAS, Brenzikofer R, Macedo DV. Reference intervals for saliva analytes collected by a standardized method in a physically active population. Clinical Biochemistry, 44(17-18):1440-4 [DOI:10.1016/j.clinbiochem.2011.09.012] [PMID]

[3] Mapes AA, Kloosterman AD, de Poot CJ. DNA in the criminal justice system: The DNA success story in perspective. Journal of forensic sciences. 2015; 60(4):851-6. [DOI:10.1111/15564029.12779] [PMID]

[4] Butler JM. Forensic DNA typing: Biology, technology and genetics of STR markers. Amsterdam: Elsevier Science; 2005.

[5] Johnson D, Peterson J, Sommers I, Baskin D. Use of forensic science in investigating crimes of sexual violence: Contrasting its theoretical potential with empirical realities. Violence Against Women. 2012; 18(2):193-222. [DOI:10.1177/1077801212440157] [PMID]

[6] Lee HC, Ladd C. Preservation and collection of biological evidence. Croatian Medical Journal. 2001; 42(3):225-8. [PMID]

[7] Raymond JJ, van Oorschot RA, Gunn PR, Walsh SJ, Roux C. Trace evidence characteristics of DNA: A preliminary investigation of the persistence of DNA at crime scenes. Forensic Science International: Genetics. 2009; 4(1):26-33. [DOI:10.1016/j. fsigen.2009.04.002] [PMID]

[8] Bozzo WR, Colussi AG, Ortiz MI, Lojo MM. DNA recovery from different evidences in 300 cases of sexual assault. Forensic Science International: Genetics Supplement Series. 2009; 2(1):1412. [DOI:10.1016/j.fsigss.2009.08.185]

[9] Khaldi N, Miras A, Botti K, Benali L, Gromb S. Evaluation of three rapid detection methods for the forensic identification of seminal fluid in rape cases. Journal of Forensic Science. 2004 49(4):1-5. [DOI:10.1520/JFS2003317] [PMID]

[10] Magalhães T, Dinis Oliveira RJ, Silva B, Corte Real F, Nuno Vieira D. Biological evidence management for DNA analysis in cases of sexual assault. The Scientific World Journal. 2015; 2015:365674. [DOI:10.1155/2015/365674] [PMID] [PMCID]

[11] Newton M. The forensic aspects of sexual violence. Best Practice \& Research Clinical Obstetrics \& Gynaecology. 2013; 27(1):77-90. [DOI:10.1016/j.bpobgyn.2012.08.020] [PMID]
[12] Stangegaard M, Hjort BB, Hansen TN, Hoflund A, Mogensen, HS Hansen AJ, et al. Automated extraction of DNA from biological stains on fabric from crime cases: A comparison of a manual and three automated methods. Forensic Science International: Genetics. 2013; 7(3):384-8. [DOI:10.1016/j.fsigen.2012.12.009] [PMID]

[13] Prodělalová J, Rittich B, Španová A, Petrová K, Beneš MJ. Isolation of genomic DNA using magnetic cobalt ferrite and silica particles. Journal of Chromatography A. 2004; 1056(1-2):43-8. [DOI:10.1016/S0021-9673(04)01448-7]

[14] Saiyed ZM, Bochiwal C, Gorasia H, Telang SD, Ramchand CN. Application of magnetic particles $\left(\mathrm{Fe}_{3} \mathrm{O}_{4}\right)$ for isolation of genomic DNA from mammalian cells. Analytical Biochemistry. 2006; 356(2):306-8. [DOI:10.1016/j.ab.2006.06.027] [PMID]

[15] John SW, Weitzner G, Rozen R, Scriver CR. A rapid procedure for extracting genomic DNA from leukocytes. Nucleic Acids Research. 1991; 19(2):408. [DOI:10.1093/nar/19.2.408] [PMID] [PMCID]

[16] Saiyed ZM, Ramchand CN, Telang SD. Isolation of genomic DNA using magnetic nanoparticles as a solid-phase support. Journal of Physics: Condensed Matter. 2008; 20(20):204153. [DOI:10.1088/0953-8984/20/20/204153] [PMID]

[17] Safarik I, Safarikova M. Magnetic nanoparticles and biosciences. Monatshefte für Chemie-Chemical Monthly. 2002; 133(6):73759. [DOI:10.1007/s007060200047] 
This Page Intentionally Left Blank 